11. Palej A.I. Strah i odinochestvo // Psihologicheskaja gazeta. 2003. №2/89. - S. 28-29.

12. Tihomirov, A.B. Psihologija zastenchivosti. Metodicheskoe posobie Tekst. / A.B. Tihomirov. Ekaterinburg : Izd-vo dvorec molodezhi, 1998. - $68 \mathrm{~s}$ 13. Shishova, T.L. Zastenchivyj nevidimka : kak preodolet' detskuju zastenchivost' / Tat'jana L'vovna Shishova. - Moskva : Rech', 2007. - 93 s.
14. Shol'c F. Nedostatki haraktera $v$ detskom vozraste: rukovodstvo dlja vospitanija v sem'e i v shkole / F. Shol'c; [per. s 3-go nem. izd., pererab. i dop. I. Trjuper]. - Moskva: Jeksmo, 2009. - $96 \mathrm{~s}$

15. Shostrom Je.Anti-Karnegi, ili Chelovek-manipuljator. M.: Dubl'-V, Del'ta-92, 1994

Надійшла до редколегії 09.10.20

Рекомендована до друку 09.10.20

Oksana Bondarchuk, PhD student

National Pedagogical Dragomanov University, Kyiv, Ukraine

\title{
PSYCHOLOGICAL FEATURES OF SHYNESS IN PRESCHOOL CHILDREN
}

The article provides a theoretical and empirical analysis of the psychological characteristics of the manifestation of shyness in preschool children. Analyzed the scientists' views on understanding of the studied phenomenon, the classification of pathological and personal forms of manifestation of personality shyness is considered. The psychological characteristics of "internally" and "externally" shy preschoolers are characterized. The positive and negative influence of shyness on the mental development of a preschool child has been substantiated. Based on a theoretical analysis of psychological literature, has given its own definition of the concept of personal shyness of a preschooler. With the help of the conducted empirical research, the structural components of personal shyness in preschool children were identified. In preschool, shyness can take the form of "internal" or "external" introspection and stimulate the search for optimal ways to overcome negative experiences using primitive isolation, autistic fantasies, etc. In our opinion, shyness in preschool children is an integrated personal quality, which is a component of emotional and volitional behavior of the child and manifests itself in the form of low self-esteem, underdeveloped communication skills, fear, need for external support and intrapersonal conflicts. The components of the self-concept of a shy preschooler have their own specific features: behavioral is characterized by fear of novelty, insecurity, conformity, lack of initiative, neglect of joint play activities, etc .; affective-evaluative component insecurity, anxiety, timidity, anxiety, loneliness, fear of social contacts, dependence on the assessments of others, emotional vulnerability to failure; the communicative component is characterized by silence, limitations, selectivity or avoidance of interaction, inability to maintain long-term contacts, express their own opinions, etc.

The results of our observational experiment showed that the presence of indicators characteristic of a high level of personal shyness was found in $21.15 \%$ of preschool children, the average level of formation in $37.63 \%$ of subjects and a low level of shyness in preschool age was found in $41.22 \%$ of children.

Keywords: preschooler, self-esteem, shyness, communication, fear.

Bulletin of Taras Shevchenko National University of Kyiv. Series "Psychology". № 1(11), pp. 14-22 (2020)

УДК 159.923

DOI: https://doi.org/10.17721/BSP.2020.1(11).3
ISSN $1728-3817$

(c) Taras Shevchenko National University of Kyiv,

Publishing and Polygraphic Center "Kyiv University", 2020

Ірина Бринза, канд. психол. наук, доц.

Південноукраїнський національний педагогічний університет імені К. Д. Ушинського, Одеса, Україна Оксана Кузнєцова, канд. психол. наук, доц. Одеська академія неперервної освіти, Одеса, Україна

\section{ПСИХОДІАГНОСТИЧНА МЕТОДИКА "ПАРЦІАЛЬНІ ПОЗИЦІЇ ЖИТТЕСТІЙКОСТІ ОСОБИСТОСТІ": РЕЗУЛЬТАТИ РОЗРОБКИ ТА АПРОБАЦІЇ}

У статті представлено теоретичний конструкт, етапи створення та результати психометричної перевірки тестопитувальника "Парціальні позиції життєстійкості особистості" (ППЖ). Розроблений тест-опитувальник вимірює параметри життєстійкості у різних типах складних, критичних життєвих ситуацій: стрес, фрустрація, конфолікт, криза, невизначеність. На етапі апробації тест-опитувальника підтверджено його надійність (методи ділення навпіл, паралельного тесту, перевірка коефіцієнту константності), валідність (методи кореляційного, факторного аналізу), дискримінативність.

Ключові слова: життєстійкість, ситуація стресу, ситуація фрустрації, ситуація кризи, ситуація конфрлікту, ситуація невизначеності, психометричні показники.

Вступ. Сучасний етап розвитку суспільства все більше набуває кризового характеру, що пронизує всі сфрери буття людини і посилює психотравматизацію у повсякденному житті. У цих умовах перед психологічною наукою і практикою стоїть завдання вивчення особистісного потенціалу, котрий виявляється у ситуації зіткнення людини з несприятливими життєвими обставинами. У цьому феноменологічному просторі чинне місце займає життєстійкість, яка розглядається як особистісний предиктор можливостей людини у подоланні стресів на основі специфічної когнітивної оцінки, смислових інтерпретацій життєвих подій, що сприяє підвищенню самоцінності та особистісному зростанню.

Саме життєстійкість визнана впливовим психологічним чинником збереження психічного та соматичного здоров'я людини в умовах стресу та перевантаження (Maddi, 2002). В останні роки увага дослідників до проблеми життєстійкості тільки зростає, запит до вивчення та аналізу проявів цієї властивості у різних аспектах відображається у значній кількості публікацій (Білоус \& Охрименко, 2015; Ульянова, 2020; Фомина \& Федосеева, 2016; Чиханцова, 2018; Mazzetti, Guglielmi \&Topa, 2020; Luceno-Moreno, Talavera-Velasco, Jaen-Diaz \& Martin-Garcia, 2020; Dymecka, Bidzan-Bluma, Bidzan, Borucka-Kotwica, Atroszko \& Bidzan, 2020; Kowalski \& Schermer 2019; Malkin, Rogaleva, Kim \& Khon, 2019). Разом із тим помічаємо десріцит психодіагностичних методик, призначених безпосередньо для вивчення життєстійкості. У цій царині на пострадянському просторі практично домінує відомий і широко розповсюджений опитувальник життєстійкості С. Мадді в адаптації Д. Леонтьєва, О. Рассказової, який має кілька модифікацій (Леонтьев \& Рассказова, 2006). Утім подальше вивчення життєстійкості, розкриття палітри її феноменологічних ознак, структурних параметрів, особливостей проявів у конкретних життєвих обставинах, вимагає розширення інструментальних можливостей із діагностики властивості. Одним із затребуваних напрямків $є$ 
діагностика життєстійкості в контексті складних, критичних життєвих ситуацій, а саме вивчення вибірковості у проявах життєстійкості під час переживання особистістю труднощів певного типу.

Мета статті: представити теоретичний конструкт, етапи створення та результати психометричної перевірки тест-опитувальника "Парціальні позиції життєстійкості особистості" (ППЖ), призначеного для діагностики особливостей прояву життєстійкості в умовах переживання складних, критичних психологічних ситуацій певного типу (стрес, фрустрація, конфлікт, криза, невизначеність).

Аналіз останніх досліджень і публікацій. Теоретичні засади розуміння життєстійкості (hardiness) запропоновані американськими дослідниками Сьюзен Кобейса і Сальватором Мадді, які розглядали її як особливу особистісну якість, котра характеризує здатність особистості витримувати стресову ситуацію, зберігаючи внутрішню збалансованість і не знижуючи успішність діяльності (Khoshaba \& Maddi, 1999). Hardiness - сукупність поглядів або переконань про себе і світ, яка дає сміливість і мотивацію для переборення труднощів (Maddi, 2002).

У роботах інших авторів життєстійкість розглядається як інтегральна характеристика, що містить значущі властивості всіх рівнів психіки людини, котрі виявляються у певних ситуаціях як єдиний комплекс, що сприяє успішному подоланню життєвих труднощів, оптимальному проживанню власного життя (Фоминова, 2012, с. 100). Л. Александрова, спираючись на психологічну теорію діяльності та психологію здібностей, описує життєстійкість як інтегральну здатність людини до діяльності з подолання життєвих труднощів, як результат розвитку і використання цієї здатності. Сама життєстійкість $є$ здатністю особистості до трансформації несприятливих обставин свого розвитку (зокрема, випробувань і задач) (Александрова, 2005).

Узагальнення наявних точок зору дозволило нам визначити життєстійкість як здатність особистості до асиміляції досвіду та розвитку в умовах переживання життєвих труднощів або в умовах складної, критичної життєвої ситуації. Функціонування властивості пов'язано з активізацією адаптивності, зокрема її емоційного і поведінкового компонентів, що забезпечують прийняття особистістю адаптаційної ситуації, у тому числі стресової, та здійснення активних дій, спрямованих на реалізацію мети (Кузнецова, 2009).

Теоретична розробка проблеми життєстійкості переважно стосується питання структури цієї властивості. Згідно з С. Мадді, "hardiness" презентує сукупність установок, атитюдів, що допомагають людині перетворювати стресогенні життєві події, трансформувати зміни у можливості. У ролі таких атитюдів розглядаються:

1) "залученість" (commitment) - упевненість у тому, що участь у подіях, які відбуваються, дає максимальний шанс знайти щось цінне і цікаве для особистості;

2) "контроль" (control) - упевненість у тому, що боротьба дозволяє впливати на результат того, що відбувається, хоча успіх не є гарантованим;

3) "виклик", "прийняття ризику" (challenge) - сприйняття особистістю подій життя як виклику і випробування себе, упевненість людини в тому, що все, що відбувається, сприяє її розвитку за рахунок знань, що здобуваються 3 досвіду - або позитивного, або негативного (Maddi, 2002; Maddi, 2004; Леонтьев \& Рассказова, 2006).

Окрім атитюдів, "hardiness" включає такі базові цінності, як кооперація (cooperation), довіра (credibility) i креативність (creativity) (Khoshaba \& Maddi, 1999).

Л. Александрова пропонує у структурі життєстійкості розглядати: 1) особистісні ресурси подолання, атитюди життєстійкості (за С. Мадді); 2) сенс, який визначає век- тор цієї життєстійкості і життя людини загалом; 3) гуманістична етика, яка задає критерії вибору сенс, шляху його досягнення і рішення життєвих задач. На думку автора, саме в такому розширеному розумінні життєстійкість може забезпечити психологічну безпеку особистості перед викликами сьогодення та майбутнього (Александрова, 2005).

Отже, теоретичний аналіз проблеми дає можливість визначити сукупність феноменологічних ознак, що охоплюють простір поняття "життєстійкість", структурні параметри цієї властивості. Відповідно до сформованих уявлень у психологічній практиці, дослідницькій роботі відбувається і діагностика життєстійкості - через оцінку названих параметрів (залученість, контроль, виклик) у психологічному портреті особистості (за Тестом життєстійкості С. Мадді в адаптації Д. Леонтьєва, О. Рассказової). Результатом є визначення загального рівня життєстійкості як здатності долати стрес і життєві труднощі та ступеня вираженості окремих їі параметрів (установок, переконань).

Практично всі автори, які приділяють увагу аналізу життєстійкості, вказують на ситуаційний аспект цього феномену - прояв в умовах життєвих труднощів, викликів, випробувань, стресів, зламів життєвого шляху. Проте залишається нез'ясованим питання ситуаційної універсальності / специфічності життєстійкості, тобто можливості диференціації у проявах цієї властивості відповідно до параметрів ситуацій, їх різновидів. На нашу думку, існують індивідуальні відмінності у проявах життєстійкості, що демонструють переважання схильності та здатності особистості до асиміляції досвіду та розвитку саме в умовах переживання певного типу складної, критичної життєвої ситуації (ситуаційна специфрічність). Це пов'язано з розбіжностями у внутрішній суб'єктивній інтерпретації складної життєвої ситуації залежно від характеру психологічного утруднення, неоднорідністю механізмів асиміляції проблемного досвіду, різноманітністю способів подолання життєвих труднощів і відповідністю їх вибору конкретним завданням (наприклад, вирішити конфлікт, витримати напруження, прийняти незворотність змін тощо). Усі ці відмінності зумовлені не стільки внутрішнім ресурсом у переборенні труднощів та наявністю hurdy-атитюдів, скільки презентують взаємопов'язаність психічних реакцій у процесі переборення труднощів під час зіткнення 3 ключовими аспектами ситуації, що визначають ії тип. Сукупність окремих ознак, що зумовлює специфіку прояву життєстійкості у складних, критичних життєвих ситуаціях певного типу, можна позначити як парціальну позицію цієї властивості. Вивчення парціальних позицій дає можливість аналізувати перспективи подолання особистістю викликів та випробувань з урахуванням різноманітності життєвого контексту, прогнозувати варіативність прояву життєстійкості в різних умовах життєдіяльності людини, наприклад у конкретних видах професійної діяльності, де закономірно переважають ситуації певного типу. Отже, можна говорити про психометричне вимірювання життєстійкості за рахунок оцінки диференціації властивості не тільки за структурними параметрами, а й за функціональними вимірами.

Постановка завдання: визначити та описати парціальні позиції життєстійкості, диференційовані за певним типом складної, критичної життєвої ситуації; розробити та здійснити психометричну перевірку тестопитувальника, призначеного для їх діагностики.

Виклад основного матеріалу. Аналіз літератури засвідчує, що феноменологія життєстійкості пов'язана 3 наявністю ситуації напруги, стресу, життєвих труднощів або в широкому розумінні - складної, критичної життєвої ситуації. Тому, розглядаючи можливості діагностики 
життєстійкості через диференційовані характеристики її проявів, необхідно звернутися до аналізу поняття психологічної ситуації.

Залежно від наукового підходу, вчені розглядають ситуацію як: 1) середовище, що детермінує активність особистості зовнішніми атрибутами ситуації, елементами середовища; 2) суб'єктивну внутрішню реальність, що $€$ власним внутрішнім життєвим простором, когнітивною репрезентацією об'єктивної реальності; 3) взаємодію особистості й середовища - особистість, поведінка якої в ситуації зумовлена зовнішніми і внутрішніми чинниками реальності, здійснює цілеспрямований діяльний вплив на ситуацію з метою створення власної ситуативної специфічності; 4) соціокультурно детерміновану інтерактивну одиницю, тобто особистість здійснює соціальне конструювання діяльності відповідно до регламентуючих нормативних ознак ситуації; 5) сукупність життєвих подій та обставин - особистість творить власний життєвий шлях і піддається трансформації під впливом життєвих подій (Ващенко \& Ананова, 2019).

У різноманітті й онтологічному багатстві ситуацій виокремлюється як одиниця наукового аналізу "складна життєва ситуація" та "критична ситуація". Складну життєву ситуацію розуміють як обумовлений внутрішніми та зовнішніми чинниками фрагмент дійсності, який на суб'єктивному рівні сприймається як психологічне ускладнення (Либина, 2008, с. 132). "Критична ситуація" визначається як ситуація неможливості реалізації внутрішніх необхідностей свого життя, серед яких: цінності, сенси, устремління, інтереси, замисли, мотиви та інше) (Василюк, 1984, с. 25, 48).

До категорії складних, критичних життєвих ситуацій, як правило, відносять фрруструючі, конфліктні, травматичні, критичні, кризові, екстремальні, важкі, стресові ситуації, ситуації психологічної загрози, ситуації невизначеності тощо (Василюк, 1984; Ващенко \& Ананова, 2019).

Різні категорії складних, критичних ситуацій мають свої відмінні характеристики. Необхідною ознакою ситуації фррустрації є наявність сильної вмотивованості досягнути мети або задовольнити потребу, а також перешкоди, що заважає цьому. Переживання ситуації фррустрації відрізняється амбівалентністю почуттів, думок і вчинків людини, що може призвести до когнітивної та поведінкової дезорієнтації, супроводжуватися станами розгубленості та відчуттям втрати орієнтирів (Василюк, 1984 , с. 36-42). Основними показниками ситуації стресу $є$ наявність специфічної психофрізіологічної реакції людини на стресовий чинник, що виявляється на індивідуальному рівні у стані зростаючої тривоги відповідно до активізації цієї реакції (Либина, 2008, с. 132). Ситуація конорлікту передбачає протистояння людей або груп із протилежно спрямованими інтересами, думками, позиціями, цілями. Конфліктні ситуації супроводжуються сильними емоційними переживаннями, погіршенням стосунків з оточенням, частіше асоціюється 3 агресією, погрозами, суперечками, ворожістю (Либина, 2008, с. 133). Ситуація невизначеності характеризується як така, що містить неочікувані і комплексні стимули (Д. Берлайн), які викликають труднощі контролю ситуації (P. Bordia), подвійну, суперечливу інформацію (Hallman). Ситуація невизначеності має також такі елементи, як новизна, суперечливість, складність (S. Budner), множинність можливості виборів і рішень, непередбачуваність прогнозу розвитку, невідомість вірогідності події, відсутність очевидних причинно-наслідкових закономірностей (Кригер, 2014).

Саме ситуації фррустрації, конфллікту, стресу, кризи та невизначеності, на наш погляд, $є$ найбільш релевантними для аналізу проявів життєстійкості. Ці прояви стосуються емоційно-особистісного виміру цієї властивості як здатності виносити негативні переживання і перетворювати їх в унікальний досвід, приймати зміни і трансформувати неприємні обставини. Власне у кожній із таких ситуацій життєстійкість особистості виявляється у найбільш розгорнутому вигляді. Разом із тим існує й своєрідність розгортання життєстійкості у кожному типі ситуацій, що є проявом парціальної позиції, у ролі елементів якої ми розглядаємо: певний спектр емоційних реакцій та почуттів, характер психологічного утруднення, механізми асиміляції проблемного досвіду, способи подолання труднощів і трансформації неприємних обставин. Наведемо авторське тлумачення цих елементів у парціальних позиціях життєстійкості, що характеризують ситуаційну специфічність та відповідають названим вище параметрам ситуацій стресу, фррустрації, конфлікту, кризи та невизначеності.

Життєстійкість у стані стресу виявляється у здатності особистості витримувати тривогу, приймати обставини, в яких не може бути задоволені потреби тут і зараз, як невід'ємну частину життя, інтегрувати переживання напруги, занепокоєння, відчуття загрози у цілісну структуру життєвого досвіду; здатність використовувати різноманітні стратегії подолання стресу (копінг).

Життєстійкість у стані фрустрації позначається як здатність внутрішньо впоратися з амбівалентністю почуттів, відчуттям розгубленості, пригніченості, зберегти відчуття жвавості та енергії; сприйняти ситуацію непереборних обмежень, неможливості реалізації мотиву як необхідну та неминучу сторону життя; здатність до асиміляції переживання фрустраційної напруги, страху, агресії як цінної частини досвіду; готовність до активних дій з усунення утруднення та перешкод у напрямку створення умов для утвердження особистого благополуччя.

Життєстійкість у стані конфлікту - здатність до опанування станів гніву, роздратування, агресії, обурення, презирства, ненависті; здатність сприйняття ситуації складності у внутрішньому світі та міжособистісних стосунках, пов'язані зі співіснуванням протилежних інтересів, позицій, як наявну реальність; синтезувати переживання напруги, боротьби, розбіжностей та дисгармонії у стосунках у цілісну структуру життєвого досвіду; здатність до перетворення конфлікту на ситуацію розвитку відносин та саморозвитку.

Життєстійкість у стані кризи - здатність особистості витримувати переживання почуття незадоволеності, образи, провини, горя, розчарування, сорому, приниження, страждання тощо та узагальнювати їх у межах картини свого життєвого шляху на рівні досвіду; приймати складні життєві події як даність, визнавати їх невід'ємною складовою персональної історії; готовність до активних дій із трансформації ситуації неможливості реалізації життєвого задуму на ситуацію психологічного відродження, перетворення або оновлення.

Життєстійкість у ситуації невизначеності виявляється як здатність виносити тривогу, сумніви та розгубленість в умовах наявності суперечливої інформації або ії̈ відсутності, непередбачуваності прогнозу розвитку подій, зіткнення з новизною або нововведеннями; інтегрувати ці переживання у цілісну структуру життєвого досвіду, прийняття світу в цілому та окремих його сегментів як відкритої системи, що постійно змінюється; здатність до реалізації стратегій конструювання майбутнього в умовах невідомості.

Представлений опис парціальних позицій, систематизація їх ознак та індикаторів дозволили розробити відповідні шкали тест-опитувальника "Парціальні позиції життєстійкості (ППЖ)" та здійснити його апробацію. 
Алгоритм конструювання оригінальної методики передбачав кілька етапів, які відповідають вимогам сучасної психометрики. На першому етапі було здійснено аналіз гіпотетичного конструкту френомену життєстійкості особистості, пошук ії ситуаційних маркерів, що презентують парціальні позиції, на основі: а) теоретичних положень та підходів; б) літературних описів феномену; в) бесід з експертами (психологами-практиками, науковцями); в) контент-аналізу творів (структуроване опитування на задану тему); г) спостереження за особистостями, які переживають стрес, конфлікт, фрустрацію, кризу, ситуацію невизначеності у процесі терапевтичної, психоконсультативної роботи.

Отримана інформація допомогла розробити комплекс критеріїв (індикаторів), що вимірюють індивідуально-психологічні особливості особистості, котрі проявляються у парціальній позиції життєстійкості.

Формою тестових завдань у опитувальнику обрані твердження. Для оцінки кожного параметру парціальної позиції життєстійкості у першому варіанті конструкту тесту було розроблено 40 тверджень, сформованих у вигляді шкал. Експертна та статистична перевірка вихідного варіанту опитувальника (аналіз проведено групою психологів-практиків та науковців у кількості 20 осіб із професійним досвідом від 7 до 27 років) показала його надзвичайно велику розмірність (об'єм) і слабкість зв'язків між окремими твердженнями тесту. Після ретельної переробки тестових тверджень у новому варіанті опитувальника залишилося 100 тверджень, що розподілені за 5 шкалами по 20 тверджень у кожній: "ситуація стресу" (С), "ситуація конфлікту" (К), "ситуація фрустрації" (Ф), "ситуація кризи" (Кр), "ситуація невизначеності" (Н).

Наведемо приклади тверджень окремих шкал.

$$
\text { Шкала }
$$

"Життєстійкість у ситуації стресу" (C)

- Випробування, які мені довелося пережити, стали для мене корисними уроками.

-У складній ситуації я завжди знаходжу внутрішню опору у власному досвіді подолання.- Я звик справлятися зі стресами самостійно і не шукаю допомоги у інших осіб.

- Коли я згадую про стреси, які мені довелося пережити, дуже засмучуюсь.

$$
\text { шкала }
$$

"Життєстійкість у ситуації конфлікту" (К)

- Переживання серйозних конфліктів часто допомагало мені більш глибоко розуміти життя.

- Як правило, навіть після гострих конфрліктів мені вдається зберігати хороші відносини з людьми.

- Якщо потрапляю в конфрліктну ситуацію на роботі або в побуті, то я вже не у змозі володіти собою настільки, щоб поглянути на неї з максимальною об'єктивністю.

Для респондентів запропоновані наступні варіанти відповідей на твердження: "безумовно, так", "можливо, так", "можливо, ні", "безумовно, ні". Також був розроблений бланк, ключ та процедура обробки даних. Відповіді на прямі твердження оцінюються так: "безумовно, так" - 4 бали, "можливо, так" - 3 бали, "можливо, ні" - 1 бал, "безумовно, ні" - 0 балів. Відповіді на "зворотні" твердження оцінюються у зворотному напрямку: "безумовно, да" - 0 бали, "можливо, да" - 1 бали, "можливо, ні" - 3 бал, "безумовно, ні" - 4 балів. Підсумок балів розраховується за кожною шкалою, обов'язково враховуються прямі та зворотні твердження, потім виводиться сумарний загальний бал за тест-опитувальником. Діапазон сумарного значення за тест-опитувальником ППЖ становить від 0 до 400 балів. Оцінка кожною шкали від 0 до 80 балів. Для стандартизації результатів тест-опитувальника використано метод процентілю, який дозволяє переводити "сири" бали у нормативні.

Новий варіант тест-опитувальника пройшов психометричну перевірку на надійність, валідність та дискримінативність.

До вибірки стандартизації увійшли студенти різних напрямків та форм навчання у віці від 18 до 58 років обох статей Південноукраїнського національного педагогічного університету імені К. Д. Ушинського, Академії архітектури і будівництва (м. Одеса). На різних етапах створення методики було залучено 340 осіб, серед яких 228 жінок, 112 чоловіків. Остання вибірка стандартизації склала 210 осіб.

Для перевірки надійності тест-опитувальника ППЖ застосовано метод "ділення тесту навпіл", який надає можливості перевірити гомогенну надійність (однорідність) тесту. Для цього кожну шкалу тест-опитувальника було поділено на дві половини, після чого числові значення обох половин тесту обчислювалися на основі розрахунку коефіцієнтів витвору моментів К. Пірсона. Отримано наступні результати кореляційного аналізу половин шкал тест-опитувальника ППЖ: шкала "ситуація фрустрації" $\left(\Phi_{1} / \Phi_{2}\right)(r=0.760, p \leq 0.01)$, шкала "ситуація кризи" $\left(\mathrm{Kp}_{1} / \mathrm{Kp}_{2}\right) \quad(r=0.888, \quad \mathrm{p} \leq 0.01)$, шкала "ситуація невизначеності" $\left(\mathrm{H}_{1} / \mathrm{H}_{2}\right)(r=0.794, \mathrm{p} \leq 0.01)$,

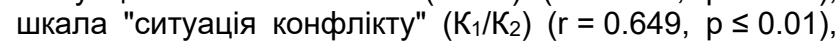
шкала "ситуація стресу" $\left(\mathrm{C}_{1} / \mathrm{C}_{2}\right)(\mathrm{r}=0.738, \mathrm{p} \leq 0.01)$. Отримана інфрормація засвідчує внутрішню узгодженість тестових завдань та їх однорідність.

Для перевірки константності або відносної незалежності результатів тесту від особистості психодіагноста проведено кореляційний аналіз (за К. Пірсоном) даних, отриманих за двома замірюваннями на одній вибірці респондентів, але різними психодіагностами. Встановлені високі статистично значущі коефіцієнти кореляцій результатів двох тестувань: шкала "ситуація фррустрації" $\left(\Phi_{\mathrm{I}} / \Phi_{\text {॥I }}\right)(r=0.895, p \leq 0.01)$, шкала "ситуація кризи" (Кр//Кр॥) $(r=0.887, \quad p \leq 0.01)$, шкала "ситуація невизначеності" $\left(\mathrm{H}_{\mathrm{I}} / \mathrm{H}_{\|}\right) \quad(r=0.893, \mathrm{p} \leq 0.01)$, шкала "ситуація конфрлікту" $\left(K_{\mathrm{I}} / \mathrm{K}_{\mathrm{II}}\right) \quad(r=0.805, p \leq 0.01)$, шкала "ситуація стресу" $\left(\mathrm{C}_{\mathrm{I}} / \mathrm{C}_{\mathrm{II}}\right) \quad(r=0.813, \mathrm{p} \leq 0.01)$. Представлені результати кореляцій підтверджують високу константність тесту до особистості психодіагноста.

Тест-опитувальник ППЖ пройшов теоретичну валідизацію, а саме перевірку на: а) очевидну, б) конструктну, в) конвергентну; г) дискримінативну (конкурентну) валідність (Анастази \& Урбина, 2001).

Доказ очевидної валідності базувався на сприйняті респондентами в цілому методики як інструменту психодіагностичного вимірювання, а саме: наявність блоку основної інформації (назва тест-опитувальника, питання що стосуються ім'я, прізвища, статі, віку, освіти та інших даних), блоку, що містить інструкцію (зрозумілість респондентами інструкції) та блоку текстових тверджень (суті, сенсу, змісту кожного твердження, несуперечності форми завдань тощо) і бланку для відповідей. Для цього було запропоноване респондентам бланк для відповідей, на якому вони помічали свої враження та зауваження за кожним запропонованим блоком. За результатами опитування вносилися корективи в оформлення кожного блоку методики.

Для перевірки конструктної валідності застосовано метод фракторного аналізу. Факторна структура тестопитувальника вибудовувалася за методами находження головних компонентів та обертання (метод ротації) (Extraction Method: Principal Component Analysis. Rotation Method: Quartimax with Kaiser Normalization). У результаті ротації групування тверджень і структура самої фракторної моделі зазнали змін. Ретельний відбір тверджень за прин- 
ципом максимально-допустимої кількості тверджень у кожному факторі, також величини фракторного ваги дозволив зберегти п'ять фракторів, кожен з яких наповнився 20 твердженнями тесту.
Результати 5-фракторної моделі тест-опитувальника представлено в табл. 1.

П'ятифакторна модель структури тест-опитувальника ППЖ

Таблиця 1

\begin{tabular}{|c|c|c|c|c|c|c|}
\hline \multirow{2}{*}{ № } & \multirow{2}{*}{ Індикатори методики } & \multicolumn{5}{|c|}{ Фактори } \\
\hline & & 1 & 2 & 3 & 4 & 5 \\
\hline 1 & $\Phi 1$ & ,052 & ,584 & ,053 & ,338 & ,025 \\
\hline 2 & $\Phi 2$ & 158 &, 252 & ,162 &,- 164 & , 147 \\
\hline 3 & \$3 & ,182 &, 260 & ,229 &,- 090 & , 178 \\
\hline 4 & $\Phi 4$ & ,121 & ,652 & ,068 &,- 098 &,- 031 \\
\hline 5 & $\Phi 5$ & ,023 & ,613 &,- 078 &,- 139 &,- 161 \\
\hline 6 & $\Phi 6$ & ,055 & ,466 &,- 001 & 150 & ,171 \\
\hline 7 & $\Phi 7$ & ,198 & ,616 &,- 004 & ,068 & ,133 \\
\hline 8 & $\Phi 8$ & ,143 &, 535 &,- 063 &, 110 &,- 321 \\
\hline 9 & $\Phi 9$ & ,152 & ,397 &,- 107 &,- 116 &,- 036 \\
\hline 10 & $\Phi 10$ & ,109 &, 509 & ,058 &,- 069 &,- 071 \\
\hline 11 & $\Phi 11$ & ,311 &, 516 &,- 033 &, 015 &, 035 \\
\hline 12 & $\Phi 12$ & ,291 & ,319 &, 043 &,- 191 &, 420 \\
\hline 13 & $\Phi 13$ & ,446 &, 425 & ,026 & ,024 &,- 141 \\
\hline 14 & \$14 & ,102 & ,495 & ,021 &,- 031 & ,129 \\
\hline 15 & $\Phi 15$ &,- 181 &, 582 &,- 062 & ,006 & ,073 \\
\hline 16 & $\Phi 16$ & 071 &, 589 & ,014 & 268 &,- 017 \\
\hline 17 & $\Phi 17$ & ,013 & ,393 & ,074 & ,029 & ,087 \\
\hline 18 & \$18 & 119 &, 437 &, 166 & 198 &,- 117 \\
\hline 19 & \$19 & 456 &, 540 &,- 102 & 075 &,- 016 \\
\hline 20 & $\Phi 20$ & ,081 & ,453 &,- 046 & ,040 &, 019 \\
\hline 21 & Kp1 & ,429 & ,377 & ,239 & ,015 & ,130 \\
\hline 22 & Кр2 & ,394 & 276 & ,226 &,- 127 &,- 379 \\
\hline 23 & Kр3 &, 392 & ,090 &,- 165 &,- 273 &, 016 \\
\hline 24 & Kp4 & ,521 & ,047 &,- 123 &,- 100 & ,047 \\
\hline 25 & Кр5 &, 505 & 054 &,- 033 &,- 156 &,- 082 \\
\hline 26 & Кр6 &, 586 & ,040 &,- 023 & ,024 &,- 012 \\
\hline 27 & Kp7 &, 545 & ,043 & ,275 &,- 048 & ,088 \\
\hline 28 & Kp8 &, 541 &, 301 & ,222 &,- 042 & ,058 \\
\hline 29 & Kp9 & ,368 & 302 & ,255 &,- 273 & ,343 \\
\hline 30 & Kp10 & ,449 &, 089 & ,198 &,- 086 & ,199 \\
\hline 31 & Kp11 & ,457 & ,242 &,- 347 & ,291 & ,085 \\
\hline 32 & Кр12 & ,648 & 121 &,- 034 & 191 &, 092 \\
\hline 33 & Kp13 &, 564 &,- 069 &,- 090 &,- 118 &,- 229 \\
\hline 34 & Kp14 & ,671 &,- 098 &,- 111 & ,222 &,- 195 \\
\hline 35 & Kp15 & ,778 &,- 135 &, 083 &,- 087 & ,006 \\
\hline 36 & Kp16 & ,494 &,- 049 &, 119 &,- 182 &,- 099 \\
\hline 37 & Kp17 &, 585 &,- 068 & ,137 & ,332 &,- 128 \\
\hline 38 & Kp18 & ,384 & ,084 & ,230 & \begin{tabular}{|l|}
,- 264 \\
\end{tabular} &,- 001 \\
\hline 39 & Кр19 & ,436 & 270 &, 181 &,- 230 &,- 244 \\
\hline 40 & Кр20 &, 541 & 255 &,- 104 &,- 040 &,- 291 \\
\hline 41 & $\mathrm{H} 1$ & ,268 & ,171 & ,088 & $\begin{array}{l}372 \\
, 372\end{array}$ & ,080 \\
\hline 42 & $\mathrm{H} 2$ &,- 036 & 098 &, 033 & ,484 & ,321 \\
\hline 43 & $\mathrm{H} 3$ & 173 &,- 030 & , 197 & ,484 &,- 262 \\
\hline 44 & $\mathrm{H} 4$ & ,401 & ,033 & ,223 &,- 353 & ,147 \\
\hline 45 & H5 &, 502 &,- 036 & 274 &,- 146 & ,273 \\
\hline 46 & $\mathrm{H} 6$ & ,282 &,- 201 &,- 068 & ,169 & ,362 \\
\hline 47 & $\mathrm{H} 7$ & ,290 & $\begin{array}{l}, 052 \\
\end{array}$ & ,091 & ,270 & ,294 \\
\hline 48 & $\mathrm{H} 8$ & 123 &,- 259 & 000 & ,299 & ,062 \\
\hline 49 & $\mathrm{H} 9$ & ,287 &,- 170 &,- 052 & ,478 & ,449 \\
\hline 50 & $\mathrm{H} 10$ &,- 029 & ,111 &,- 065 & ,411 &,- 012 \\
\hline 51 & $\mathrm{H} 11$ & ,066 &,- 059 & ,239 & ,506 &,- 022 \\
\hline 52 & $\mathrm{H} 12$ & 367 & 133 &, 161 &,- 445 & ,189 \\
\hline 53 & $\mathrm{H} 13$ & ,095 & ,206 & ,059 & ,243 &,- 055 \\
\hline 54 & $\mathrm{H} 14$ & ,257 & ,103 & ,031 & ,665 & ,274 \\
\hline 55 & H15 &,- 072 & 131 & ,270 & ,463 & ,387 \\
\hline 56 & H16 & ,172 & 421 & ,216 & ,433 & ,076 \\
\hline 57 & $\mathrm{H} 17$ & ,168 & ,291 & ,085 & ,268 & ,319 \\
\hline 58 & $\mathrm{H} 18$ & ,204 &,- 128 & ,228 & ,587 &,- 286 \\
\hline 59 & H19 & 124 & 021 &, 104 & ,314 & ,198 \\
\hline 60 & $\mathrm{H} 2 \mathrm{O}$ & ,295 & ,065 &,- 059 & ,376 & ,357 \\
\hline 61 & K1 & 208 & 306 & ,484 & 186 &,- 058 \\
\hline 62 & K2 & ,283 & 034 &,- 285 &,- 057 & ,133 \\
\hline 63 & K3 &,- 042 &, 280 &, 527 &, 116 &,- 184 \\
\hline 64 & K4 & ,059 & ,187 & $\begin{array}{l}, 299 \\
\end{array}$ &,- 034 &,- 020 \\
\hline
\end{tabular}




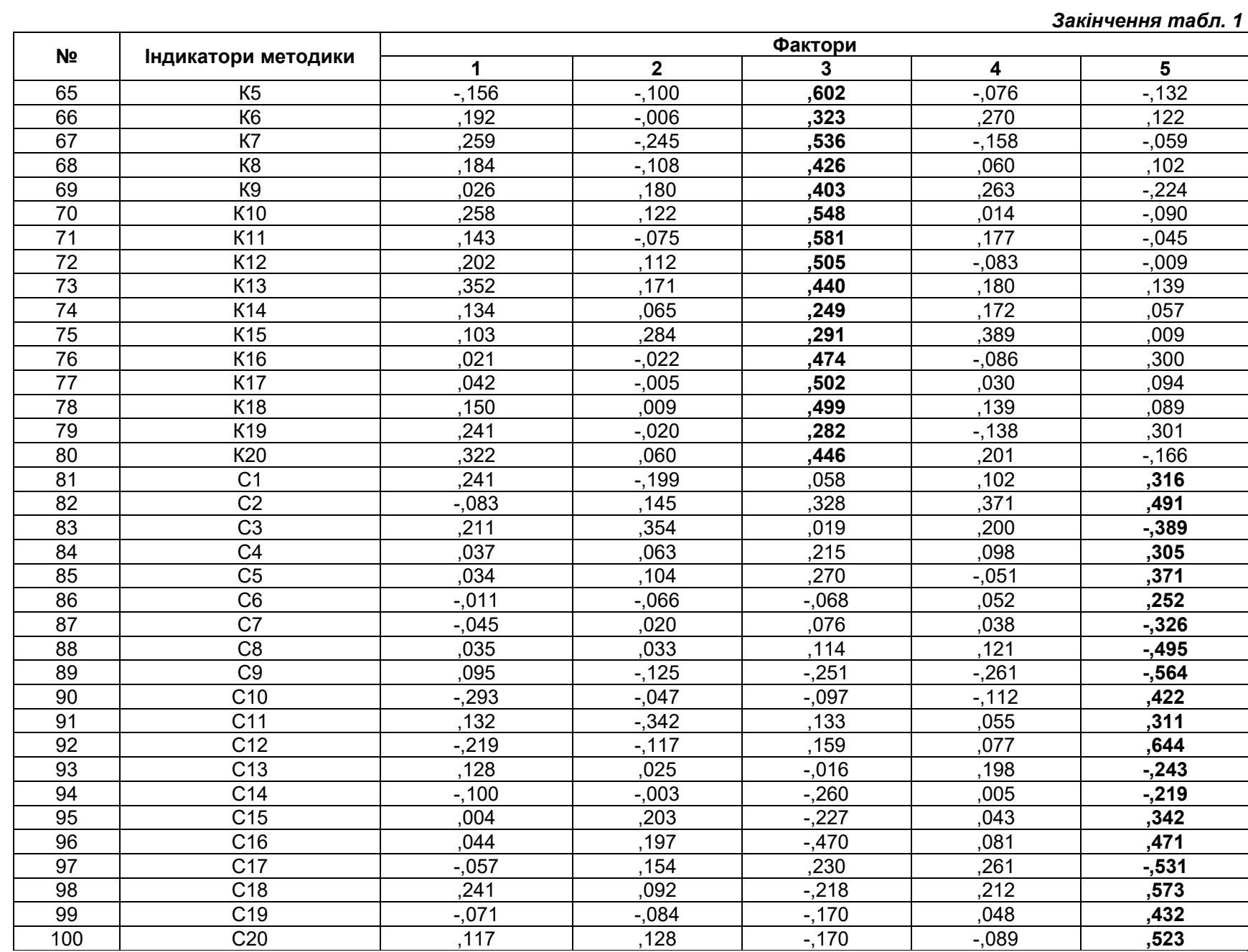

Примітка. Тут і далі: 1) нулі та коми пропущені; 2) умовні позначення: Ф1-Ф20 - індикатори шкали "Життєстійкість у ситуації фрустрації", Кр1-Кр20 - індикатори шкали "Життєстійкість у ситуації кризи", Н1-Н2 - індикатори шкали "Життєстійкість у ситуації невизначеності", К1-К20 - індикатори шкали "Життєстійкість у ситуації конфлікту", С1-С20 - індикатори шкали "Життєстійкість у ситуації стресу"

Перший фрактор об'єднав показники шкали "Життєстійкість у ситуації кризи", що пояснює 51,44\% дисперсії від загальної матриці кореляцій, у другому факторі компактно представлені твердження шкали "Життєстійкість у ситуації фррустрації" (48,17\% дисперсії), третій фрактор охоплює показники шкали "Життєстійкість у ситуації конфрлікту" (43,51\% дисперсії), четвертий фактор презентує індикатори шкали "Життєстійкість у ситуації невизначеності" (34,81\% дисперсії), п'ятий - індикатори шкали "Життєстійкість у ситуації стресу" (38,75\% дисперсії). Отже, фракторизація масиву даних після обер- тання (ротації) надала 5-ти фракторну модель, яка підтвердила вихідний теоретичний конструкт методики.

Для перевірки конвергентної валідності, що спрямована на встановлення ступеню зв'язку з родовою (еталонною) методикою застосовано метод кореляційного аналізу за методом К. Пірсона. Родовою методикою виступив Тест життєстійкості С.Мадді в адаптації Д. Леонтьєва, О. Рассказової (Леонтьев \& Рассказова, 2006). Результати кореляційного аналізу представлено в табл. 2.

Значимі коефіцієнти кореляцій між показниками тест-опитувальників життєстійкості

таблиця 2 та парціальних позицій життестійкості особистості

\begin{tabular}{|c|c|c|c|c|}
\hline \multirow{2}{*}{$\begin{array}{c}\text { Показники парціальних } \\
\text { позицій життєстійкості } \\
\text { (ПпЖ) }\end{array}$} & \multicolumn{4}{|c|}{ Показники життєстійкості (за методикою С. Мадді в адаптації Д. Леонтьєва, О. Рассказової) } \\
\hline & 3 & К & חP & Іж \\
\hline$\phi$ & $233^{* *}$ & $212^{* *}$ & $376^{* *}$ & $244^{* *}$ \\
\hline Кр & & & $286^{* *}$ & \\
\hline $\mathrm{H}$ & $268^{* *}$ & $266^{* *}$ & $292^{* *}$ & $293^{* *}$ \\
\hline $\mathrm{K}$ & $-259^{* *}$ & $-282^{* *}$ & $-203^{* *}$ & $-278^{* *}$ \\
\hline $\mathrm{C}$ & $244^{* *}$ & $279^{\star *}$ & $207^{* *}$ & $248^{\star \star}$ \\
\hline $3 \Pi$ & $208^{* *}$ & $208^{* *}$ & $339^{* *}$ & $227^{* *}$ \\
\hline
\end{tabular}

Примітка. 2) ** $\left.\left.\mathrm{p} \leq 0.01,{ }^{*} \mathrm{p} \leq 0.05 ; 3\right) \mathrm{n}=210 ; 4\right)$ показники парціальних позицій життєстійкості: Ф - шкала ситуації фрустрації; Кр - шкала ситуації кризи; Н - шкала ситуації невизначеності; К - шкала ситуації конфрлікту; С - шкала ситуації стресу; ЗП - шкала загального показника тест-опитувальника; 5) показники життєстійкості: 3 - залученість, К - контроль, ПР - прийняття ризику, Іж - індекс життєстійкості. 
Значення коефіцієнтів кореляцій, що представлені в табл. 1, вказують на статистично значущі зв'язки ( $\leq 0.01)$ між показниками тест-опитувальників, які аналізуються. Практично всі показники тест-опитувальників виявили додатні кореляції, крім показника К (шкала прояву життєстійкості у ситуації конфлікту). Він від'ємно пов'язаний зі всіма шкалами опитувальника життєстійкості за Д. Леонтьєвим і О. Рассказової. Таким чином, з одного боку, наявність кореляцій між авторським опитувальником та аналогічним еталонним (родовим) опитувальником (вже психометрично перевіреним) вказує на те, що розроблена методика вимірює ту ж саму психологічну якість, що й еталонний; з іншого боку, низькі (від 0,20 до 0,30) та середні (від 0,30 до 0,50) значення коефіцієнтів кореляцій засвідчують, що нова методика має інше теоретичне обґрунтування конструкту. Нова методика спрямована на оцінку парціальних позицій життєстійкості особистості, ситуаційно обумовлених їі проявів, які розгортаються у повсякденному житті людини, на відміну від діагностики особистісної диспозиції - системи переконань про себе, про світ, про стосунки зі світом, котрі вимірюються в еталонному тестопитувальнику життєстійкості. Отож, авторський тест- опитувальник ППЖ - це новий психодіагностичний інструмент, що вимірює життєстійкість у різних парціальних позиціях: у ситуаціях фррустрації, кризи, невизначеності, конфлікту та стресу.

Для перевірки дискримінативної або конкурентної валідності обрано метод паралельного тесту. У ролі паралельних тестів відібрані перевірені практикою методики, що мають підтверджений високий ступінь надійності та валідності: "Тест-опитувальник діагностики показників переживання психологічної кризи" (ПК) (О. Саннікова, І. Бринза), що діагностує десять субшкал: Кр1 (емоційне занепокоєння), Кр2 (емоційне напруження), Кр3 (емоційні деструкції), Кр4 (емоційне вигоряння), Кр5 (ставлення до себе), Кр6 (ставлення до інших), Кр7 (ставлення до майбутнього), Кр8 (ставлення до праці), Кр9 (поведінка), Кр10 (загальне самопочуття), Крзп (загальний показник переживання кризи) (Санникова \& Брынза, 2000); методика "Самооцінка психічних станів за Г. Айзенком" (СПС), що вимірює такі характеристики, як: Т (тривожність), Фр (фррустрація), А (агресивність), Р (ригідність) (Практическая психодиагностика. Методики и тесты, 2012).

В табл. 3 представлені коефіцієнти кореляцій за методом К. Пірсона між показниками паралельних тестів.

Таблиця 3 Коефіцієнти кореляцій між показниками методик, що спрямовані на перевірку дискримінативної (конкурентної) валідності

\begin{tabular}{|c|c|c|c|c|c|c|}
\hline \multirow{2}{*}{$\begin{array}{c}\text { Показники } \\
\text { паралельних тесті }\end{array}$} & \multicolumn{6}{|c|}{ Показники парціальних позицій життєстійкості (ППЖ) } \\
\hline & $\Phi$ & Кр & $\mathbf{H}$ & $\mathbf{K}$ & C & $3 \Pi$ \\
\hline Kp1 & -027 & $-284^{*}$ & $-282^{*}$ & -053 & 000 & -075 \\
\hline Kp2 & -037 & $-224^{* *}$ & $-296^{*}$ & $-328^{* *}$ & -072 & $-203^{*}$ \\
\hline Kp3 & -043 & $-205^{*}$ & -050 & $-208^{*}$ & -042 & -076 \\
\hline Kp4 & -065 & $-227^{* *}$ & $-203^{*}$ & -079 & -013 & $-294^{*}$ \\
\hline KP6 & -047 & $-218^{\star *}$ & -029 & 018 & -059 & -035 \\
\hline Kp7 & -043 & $-218^{\star \star}$ & -015 & -032 & 003 & -025 \\
\hline Kp9 & -041 & $-233^{* *}$ & -079 & $-203^{*}$ & -006 & $-280^{*}$ \\
\hline Крзп & -041 & $-229^{* *}$ & -063 & $-288^{*}$ & -018 & -071 \\
\hline$T$ & 010 & 001 & 028 & $-210^{*}$ & $231^{* *}$ & 037 \\
\hline$\Phi p$ & $386^{\star *}$ & $084^{*}$ & 070 & -071 & 072 & 078 \\
\hline A & 011 & -049 & 065 & $257^{\star *}$ & 036 & 068 \\
\hline$P$ & $-207^{\star *}$ & -033 & -051 & -037 & 046 & -012 \\
\hline
\end{tabular}

Візуальний аналіз табл. 3 демонструє багатозначні кореляції ( $\leq 0.01 ; p \leq 0.05)$ між показниками, що вивчаються. Парціальний показник життєстійкості шкала "ситуація

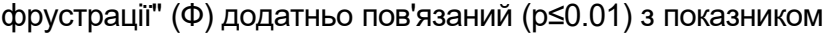
психічних станів "фрустрація" (Фр), від'ємно - $з$ показни-

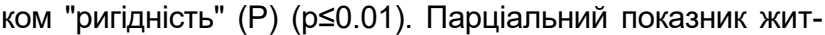
тєстійкості шкала "ситуація кризи" (Кр) від'ємно статистично значимо пов'язаний $(p \leq 0.01$; $p \leq 0.05)$ з восьми показниками психологічної кризи, серед яких: "емоційне занепокоєння" (Кр1), "емоційне напруження" (Кр2), "емоційні деструкції" (Кр3), "емоційне вигоряння" (Кр4). Парціальний показник життєстійкості шкала "ситуація невизначеності" $(\mathrm{H})$ має від'ємні зв'язки $(p \leq 0.05)$ тільки з показниками психологічної кризи: "емоційне занепокоєння" (Кр1), "емоційне напруження" (Кр2), "емоційне вигоряння" (Кр4). Парціальний показник життєстійкості шкала "ситуація конфлікту" (К) демонструє від'ємні зв'язки ( $\leq 0.01 ; p \leq 0.05)$ з показниками психологічної кризи, а саме: "емоційне напруження" (Кр2), "емоційні деструкції" (Кр3), "деструктивна поведінка" (Кр9), "загальний показник переживання психологічної кризи" (Крзп); додатні (р $\leq 0.01)$ - $з$ показником психічного стану "агресія" (А). Парціальний показник життєстійкості шкала "ситуація стресу" позитивно і статистично значимо пов'язаний $(p \leq 0.01 ; p \leq 0.05)$ з показником психічного стану "тривожність" (Т). Загальний показник парціальних позицій життєстійкості (3П) негативно і статистично значимо ( $\leq 0.05)$ пов'язаний тільки з показниками психологічної кризи: "емоційне напруження" (Кр2), "емоційне вигоряння" (Кр4) і "деструктивна поведінка" (Кр9).
Отримані результати можна проінтерпретувати наступними положеннями. Перше, негативні зв'язки між більшістю порівняних показників методик вказують на протилежну лінійну їх залежність, а саме, збільшення, домінування життєстійких властивостей особистості перешкоджає і зменшує внутрішню психічну напругу в критичних ситуаціях фрустрації, кризи, невизначеності, конфлікту, стресу за рахунок здатності виносити негативні переживання, перетворювати їх, приймати зміни і трансформувати неприємні обставини. I навпаки, підвищення і актуалізація деструктивних чинників (тривоги, агресії, паніки, фррустрації, ригідності та інше) приводить до зниження життєстійкості особистості, але не тотально на загальному рівні, а з урахуванням ситуаційної специфічності.

Друге, невелика сукупність зв'язків, що встановлені між показниками парціальних шкал життєстійкості і показниками психологічної кризи, психічних станів вказує на їх єдність за психологічною сутністю (підтвердження конвергентної валідності за певними шкалами парціальної життєстійкості), а більша за кількістю відсутність таких зв'язків - на їх відмінності (підтвердження дискримінативної валідності), що в цілому доводить конкурентну валідність (спроможність) окремих шкал і тестопитувальника, у цілому.

Для перевірки дискримінативності кожного твердження тесту та конструкту у цілому обрано статистичний метод визначення значень коефіцієнтів кореляцій (за Ч. Спірменом) між сумою балів кожної шкали зі значеннями загального показника (ЗП). Отримано наступні результати: за шкалою $Ф(p=0.557, p \leq 0.01)$, шкалою Кр 
$(\mathrm{p}=0.539, \mathrm{p} \leq 0.01)$, шкалою $\mathrm{H}(\mathrm{p}=0.738, \mathrm{p} \leq 0.01)$, шкалою $\mathrm{K}(\mathrm{p}=0.526, \mathrm{p} \leq 0.01)$, шкалою $\mathrm{C}(\mathrm{p}=0.562, p \leq 0.01)$. Наведені результати демонструють статистично значущі додатні кореляційні зв'язки між всіма показниками шкал із загальним показником тест-опитувальника. Крім того розраховано показник коефіцієнта $\delta$ Фергюсона окремо для кожної шкали тесту (Клайн, 1994). Результати обрахування показують високий рівень дискримінативності за всіма шкалами (0,95-0,99). Отримані дані підтверджують здатність тесту диференціювати результати респондентів відносно до максимального та мінімального балу.

Підводячи підсумок етапів апробації, психометричної перевірки тест-опитувальника ППЖ на ефективність необхідно зазначити, що вся сукупність статистичних доказів підтверджує надійність, валідність, дискримінативність тесту. Тест-опитувальник "Парціальні позиції життєстійкості" є релевантним діагностичним інструментом, що спрямований на оцінку специфрічності життєстійкості особистості в ситуаціях стресу, конфлікту, фрустрації, кризи, невизначеності та може використовуватися як у науковій, так і практичній психологічній діяльності.

Висновки. Теоретичний аналіз проблеми життєстійкості та її діагностики дозволив виокремити специфічні ознаки проявів цієї властивості у складних життєвих ситуаціях певного типу і запропонувати психодіагностичну методику, призначену для їх вимірювання. Як критерії диференціації проявів життєстійкості розглядаються особливості переживання складних, критичних життєвих ситуацій: певний спектр емоційних реакцій та почуттів, характер психологічного утруднення, механізми асиміляції проблемного досвіду, способи подолання труднощів і трансформації неприємних обставин. Найбільш релевантними для аналізу проявів життєстійкості $€$ наступні типи складних життєвих ситуацій: фррустрація, конфллікт, стрес, криза та невизначеність. Певні особливості прояву цієї властивості у кожному типі ситуацій можна позначити як ситуативно зумовлену специфічність або парціальні позиції життєстійкості.

На основі висловлених теоретичних уявлень розроблено тест-опитувальник "Парціальні позиції життєстійкості (ППЖ)", що не має аналогів серед існуючих психодіагностичних засобів із досліджуваного напрямку. Проведено стандартизацію тест-опитувальника, підтверджено достатній рівень його надійності, валідності, дискримінативності. Результати апробації засвідчили відповідність методики психометричним вимогам, що дозволяє використовувати її як у наукових, так і у практичних цілях.

Використання тест-опитувальника у практиці діагностики життєстійкості дозволяє перейти до вивчення не тільки когнітивних конструктів (hardy-аттитюдів), а й емоційно-особистісного виміру властивості, що виявляється в особливостях переживання складних життєвих ситуацій, прояву зусиль із подолання особистістю викликів та випробувань з урахуванням різноманітності життєвого контексту. Отримані за допомогою тестопитувальника ППЖ дані можна використовувати в психоконсультаційній, психотерапевтичній роботі, у процесі професійного відбору кадрів, для складання варіативного прогнозу поведінки та розвитку особистості у складних життєвих обставинах.

Список використаних джерел

1. Анастази А. Урбина С. Психологическое тестирование. - СПб. Питер, 2001. - 688 с.

2. Александрова Л. А. О составляющих жизнестойкости личности как основе ее психологической безопасности в современном мире. Известия ЮФУ. Технические науки. 2005. №7. URL: https://cyberleninka.ru/ article/n/o-sostavlyayuschih-zhiznestoykosti-lichnosti-kak-osnove-eepsihologicheskoy-bezopasnosti-v-sovremennom-mire/viewer
3. Білоус Р.М., Охрименко В.О. Вплив часової перспективи на життєстійкість молоді. Теоретичні і прикладні проблеми психології. - 2015. № 3 (38). - C46-53.

4. Бурлачук Л. Ф., Морозов С. М. Словарь-справочник по психодиагностике. - СПб.: Питер, 2000. - 462 с

5. Василюк Ф. Е. Психология переживания: анализ преодоления критических ситуаций. - М.: МГУ, 1984. - 187 с.

6. Ващенко І., Ананова І. Особистість і життєві ситуації у концептуальному просторі психологічної науки. Проблеми сучасної психології. 2019. - Вип. 46. - С. 59-87

7. Клайн П. Справочное руководство по конструированию тестов. К.: ПАН ЛТД, 1994. - 276 с.

8. Кригер Е.А. Типы ситуаций неопределенности в профессиональной деятельности педагога. Вестник ТГПУ. 2014. №1. URL: https://cyberleninka.ru/article/n/tipy-situatsiy-neopredelennosti-v-

professionalnoy-deyatelnosti-pedagoga

9. Кузнецова О. В. Адаптивный потенциал жизнестойкой личности. Наука і освіта. 2009. - № 8. - С. 26-29.

10. Леонтьев Д. А., Рассказова Е.И. Тест жизнестойкости. - М.: Смысл. 2006. - 63 с

11. Либина А. В. Совладающий интеллект: человек в сложной жизненной ситуации. - М.: Эксмо, 2008 - 400 с.

12. Практическая психодиагностика. Методики и тесты: учебное пособие / ред. - сост. Д. Я. Райгородский. - Самара: Издательский Дом "БАХРАХ", 2012. - 672 с

13. Санникова О. П., Брынза И. В. Тест-опросник переживания профессионального кризиса (факторный анализ). Вісник Харківського університету. Серія Психологія. - 2000. - №472. - С. 28-32.

14. Ульянова Т.Ю. Співвідношення життєстійкості та емоційності особистості. Науковий вісник Херсонського державного університету. Серія Психологічні науки. - 2020. - №3. - С. 72-80.

15. Фомина Н.Ф., Федосеева Т.Е. Исследование показателей жизнестойкости в аспекте личности профессионала. Современные проблемы науки и образования. - 2016. - № 6.; URL: http://www.scienceeducation.ru/ru/article/view?id=25947.

16. Фоминова А.Н. Жизнестойкость личности: монография. - Москва: МПГУ, Прометей, 2012. - 152 с.

17. Чиханцова О. Життєстійкість та її зв'язок із цінностями особистості. Проблеми сучасної психології. - 2018. - Вип. 42. - С. 211-231.

18. Dymecka, J., Bidzan-Bluma, I., Bidzan, M., Borucka-Kotwica, A., Atroszko, P., Bidzan, M. Validity and reliability of the Polish adaptation of the Health-Related Hardiness Scale - the first confirmatory factor analysis results for a commonly used scale. Health Psychology Report. 2020. T. 8. Vol. 3. P. 248- 262

19. Khoshaba, D., \& Maddi, S. Early Antecedents of Hardiness. Consulting Psychology Journal, Spring 1999. Vol. 51, (n2), 1999. P. 106- 117.

20. Kowalski, CM., Schermer, J. A. Hardiness. Perseverative Cognition, Anxiety and Health-Related Outcomes: A Case for and Against Psychological Hardiness. Psychologycal Reports. 2019. T. 122. Vol. 6. P. 2096-2118.

21. Luceno-Moreno, L., Talavera-Velasco, B., Jaen-Diaz, M., MartinGarcia, J. Hardy Personality Assessment: Validating the Occupational Hardiness Questionnaire in Police Officers. Professional PsychologyResearch and Practice. 2020. T 51. Vol. 3. P. 297- 303

22. Maddi, S. Hardiness: An operationalization of existential courage. Journal of Humanistic Psychology, 2004. 44, 279-298.

23. Maddi, S. The Story of Hardiness : Twenty Years of Theorizing, Research, and Practice. Consulting Psychology Journal: Pracice and Research. 2002. Vol. 54. №3. P. 173-185.

24. Malkin, V., Rogaleva, L., Kim, A., Khon, N. The Hardiness of Adolescents in Various Social Groups Frontiers in Psychology. 2019. Vol. 10.

25. Mazzetti, G., Guglielmi, D., Topa, G. Hard Enough to Manage My Emotions: How Hardiness Moderates the Relationship Between Emotional Demands and Exhaustion. Frontiers in Psychology. 2020. Vol. 11.

\section{References}

1. Anastazi A. Urbina S. Psihologicheskoe testirovanie. SPb.: Piter, 2001. $688 \mathrm{~s}$.

2. Aleksandrova L. A. O sostavljajushhih zhiznestojkosti lichnosti kak osnove ee psihologicheskoj bezopasnosti v sovremennom mire. Izvestija JuFU. Tehnicheskie nauki. 2005. \#7. URL: https://cyberleninka.ru/article/n/osostavlyayuschih-zhiznestoykosti-lichnosti-kak-osnove-ee-psihologicheskoybezopasnosti-v-sovremennom-mire/viewer

3. Bilous R.M., Ohrimenko V.O. Vpliv chasovoï perspektivi na zhittestijkist' molodi. Teoretichni i prikladni problemi psihologiï. 2015. \# 3 (38). S46-53.

4. Burlachuk L. F., Morozov S. M. Slovar'-spravochnik po psihodiagnostike SPb.: Piter, 2000. $462 \mathrm{~s}$.

5. Vasiljuk F. E. Psihologija perezhivanija: analiz preodolenija kriticheskih situacij. M.: MGU, 1984. $187 \mathrm{~s}$

6. Vashhenko I., Ananova I. Osobistist' i zhittevi situaciï u konceptual'nomu prostori psihologichnoï nauki. Problemi suchasnoï psihologiï. 2019. Vip. 46. S. 59-87.

7. Klajn P. Spravochnoe rukovodstvo po konstruirovaniju testov. K.: PAN LTD, 1994. $276 \mathrm{~s}$

8. Krizisnaja psihologija. Spravochnik prakticheskogo psihologa [sost. S. L. Solov'eva]. M.: AST; SPb.: Sova, 2008. 286 s.

9. Kuznecova O. V. Adaptivnyj potencial zhiznestojkoj lichnosti. Nauka i osvita. 2009. № 8. S. 26-29.

10. Leont'ev D. A., Rasskazova E. I. Test zhiznestojkosti. M.: Smysl. 2006. $63 \mathrm{~s}$. 
11. Libina A. V. Sovladajushhij intellekt: chelovek v slozhnoj zhiznennoj situacii. M.: Jeksmo, 2008. $400 \mathrm{~s}$

12. Prakticheskaja psihodiagnostika. Metodiki i testy: uchebnoe posobie / red.sost. D. Ja. Rajgorodskij. Samara: Izdatel'skij Dom "BAHRAH", 2012. 672 s.

13. Sannikova O. P., Brynza I. V. Test-oprosnik perezhivanija professional'nogo krizisa (faktornyj analiz). Visnik Harkivs'kogo universitetu. Serija Psihologija. 2000. №472. S.28-32.

14. Ul'janova T.Ju. Spivvidnoshennja zhittestijkosti ta emocijnosti osobistosti. Naukovij visnik Hersons'kogo derzhavnogo universitetu. Serija Psihologichni nauki. 2020. \#3. S.72-80.

15. Fomina N.F., Fedoseeva T.E. Issledovanie pokazatelej zhiznestojkosti $v$ aspekte lichnosti professionala. Sovremennye problemy nauki i obrazovanija. - 2016. - \# 6.; URL: http://www.scienceeducation.ru/ru/article/view?id=25947.

16. Fominova A.N. Zhiznestojkost' lichnosti: monografija. Moskva MPGU, Prometej, 2012. $152 \mathrm{~s}$

17. Chihancova O. Zhittestijkist' ta iii zv'jazok iz cinnostjami osobistosti. Problemi suchasnoï psihologiï. 2018. Vip. 42. S. 211-231.

18. Dymecka, J., Bidzan-Bluma, I., Bidzan, M., Borucka-Kotwica, A., Atroszko, P., Bidzan, M. Validity and reliability of the Polish adaptation of the Health-Related Hardiness Scale - the first confirmatory factor analysis results for a commonly used scale. Health Psychology Report. 2020. T. 8. Vol. 3. P. 248- 262
19. Khoshaba, D., \& Maddi, S. Early Antecedents of Hardiness. Consulting Psychology Journal, Spring 1999. Vol. 51, (n2), 1999. P. 106- 117.

20. Kowalski, CM., Schermer, J. A. Hardiness. Perseverative Cognition, Anxiety and Health-Related Outcomes: A Case for and Against Psychological Hardiness. Psychologycal Reports. 2019. T. 122. Vol. 6. P. 2096- 2118.

21. Luceno-Moreno, L., Talavera-Velasco, B Jaen-Diaz, M., MartinGarcia, J. Hardy Personality Assessment: Validating the Occupational Hardiness Questionnaire in Police Officers. Professional PsychologyResearch and Practice. 2020. T 51. Vol. 3. P. 297- 303.

22. Maddi, S. Hardiness: An operationalization of existential courage. Journal of Humanistic Psychology, 2004. 44, 279-298.

23. Maddi, S. The Story of Hardiness : Twenty Years of Theorizing, Research, and Practice. Consulting Psychology Journal: Pracice and Research. 2002. Vol. 54. №3. P. 173-185.

24. Malkin, V., Rogaleva, L., Kim, A., Khon, N. The Hardiness of Adolescents in Various Social Groups Frontiers in Psychology. 2019. Vol. 10.

25. Mazzetti, G., Guglielmi, D., Topa, G. Hard Enough to Manage My Emotions: How Hardiness Moderates the Relationship Between Emotional Demands and Exhaustion. Frontiers in Psychology. 2020. Vol. 11.

Надійшла до редколегії 29.08.20

Рекомендована до друку 05.10.20

Iryna Brynza, PhD (Psychological Sciences), Associate Prof.,

K.D. Ushinsky South Ukrainian National Pedagogical University, Odessa, Ukraine

Oksana Kuznetsova, PhD (Psychological Sciences), Associate Prof.

Odessa Academy of Continuing Education, Odessa, Ukraine

\section{TEST QUESTIONNAIRE "PARTIAL POSITIONS OF PERSONALITY HARDINESS": RESULTS OF CREATION AND APPROBATION}

The article presents the theoretical construction, stages of creation and results of psychometric verification of the test questionnaire "Partial positions of personality hardiness" (PPH). Hardiness stands for the ability of an individual to assimilate experience and development during life's difficulties. Partial positions of personality hardiness cover a specific manifestation of the characteristics in different types of hardships, which is implemented in a range of emotional reactions and feelings, the nature of psychological difficulties, mechanisms of assimilation of problem experience, coping strategies and transformation of unpleasant circumstances.

The developed test questionnaire contains 100 statements, distributed on 5 scales of 20 statements each: "hardiness in a situation of stress", "hardiness in a situation of frustration", "hardiness in a situation of conflict", "hardiness in a crisis", "resilience in situations of uncertainty". The algorithm of the original method construction provided for several stages that meet the requirements of modern psychometrics. At the stage of approbation of the test questionnaire its reliability (method of division in half, parallel test, check of independence of results from the personality of the diagnostician), obvious, constructive, convergent; competitive validity (methods of correlation, factor analysis), discriminativeness has been verified. The presence of correlations between the indicators of the PPH test questionnaire and the S. Muddy Test of hardiness (adapted by D. Leontiev, O. Rasskazova) indicates that the developed method measures the same psychological quality as the reference test, but low (from 0.20 to 0.30 ) and average (from 0.30 to 0.50 ) values of correlation coefficients indicate that the new method has different theoretical construction grounds. Comparison of data between the test-questionnaire of PPH and parallel tests ("Test-questionnaire of indicators' diagnostics of psychological crisis experience" (PE) (O. Sannikova, I. Brynza), and a method of "Self-assessment of mental states according to G. Eysenck") showed existence of negative correlations between of the majority of comparative methods' indicators of $(p \leq 0.01 ; p \leq 0.05)$.

The results of approbation approved the conformity of the created method in accordance with psychometric requirements, which allows to use it both for scientific and practical purposes.

Keywords: hardiness, stress situation, frustration situation, crisis situation, conflict situation, uncertainty situation, psychometric indicators.

Bulletin of Taras Shevchenko National University of Kyiv. Series "Psychology". № 1(11), pp. 22-26 (2020) УДК 159.923

DOI: https://doi.org/10.17721/BSP.2020.1(11).4
ISSN 1728-3817

(C) Taras Shevchenko National University of Kyiv,

Publishing and Polygraphic Center "Kyiv University", 2020

\section{Юліана Букатару, канд. фармацевт. наук, асист. Вищий державний навчальний заклад України "Буковинський державний медичний університет", Чернівці, Україна \\ Марина Рева, канд. психол. наук, ст. викладач Полтавський національний педагогічний університет імені В.Г.Короленка, Полтава, Україна Ксенія Березяк, викладач \\ Львівський державний університет безпеки життєдіяльності, Навчально-науковий інститут психології та соціального захисту, Львів, Україна}

\section{ФОРМУВАННЯ ТА КЛАСИФІКАЦІЯ ПСИХОСОМАТИЧНИХ РОЗЛАДІВ}

Базовими прийнято вважати три аспекти психосоматичних дефектів: психічні розлади, які проявляються в соматичній сфері, психічні розлади, які сформувались на основі соматичної патології, соматичні розлади, що зумовлені психічними патологіями, аномаліями особистості та психогенними чинниками. Ключовими ознаками можуть бути: органічні симптоми, фізіологічні кореляти тривожності, симптоми, які проявляються під час формування та розвитку психосоматичних розладів.

Ключові слова: стрес, фармакологічна корекція, психосоматози, медична психологія, патопсихологія.

Вступ. Сучасний високотехнологічний інформаційно насичений світ зумовлює загострення проблеми зростання психологічного навантаження і стресів, що надає проблемі здоров'я та хвороби особливого значення. Психічні аномалії можуть здійснювати вплив на життя будь-якої людини не залежно від ії статусу, статку, професії. Психічні розлади можуть стати причиною тяжких страждань, які випадають на долю людини, або навпаки, стати джерелом натхнення та енергії. За рахунок того, що, на сучасному етапі, розрізняють два основних ком- 